\title{
MODEL PEMBELAJARAN SOMATIS, AUDITORI, VISUAL DAN INTELEKTUAL (SAVI): IMPLEMENTASI PADA MATA PELAJARAN TEKNOLOGI INFORMASI DAN KOMUNIKASI (TIK) DI SMP
}

\author{
Evy Maya Stefany \\ Teknologi Pembelajaran, Pascasarjana, Universitas Pendidikan Ganesha \\ Singaraja, 81116, Indonesia \\ maya_stefany@ymail.com
}

\begin{abstract}
Abstrak
Pendidikan adalah segala situasi hidup yang mempengaruhi pertumbuhan individu sebagai pengalaman belajar yang berlangsung dalam segala lingkungan dan sepanjang hidup. Sebagai konsekuensi logis, pendidikan selalu dihadapkan pada masalah-masalah baru. Mutu pendidikan dipermasalahkan jika hasil pendidikan belum mencapai taraf seperti yang diharapkan. Permasalahan mutu pendidikan lebih terletak pada masalah pemrosesan pendidikan. Selanjutnya kelancaran pemrosesan pendidikan ditunjang oleh komponen pendidikan yang terdiri dari peserta didik, tenaga pendidikan, kurikulum. Dalam pembelajaran, TIK merupakan bagian dari ranah ilmu pengetahuan yang telah dimasukkan ke dalam kurikulum pendidikan. Oleh karena itu diperlukan pendekatan pembelajaran yang sesuai, dan guru diharapkan hanya sebagai fasilitator dalam proses belajar mengajar. Teori pembelajaran somatis, auditori, visual, dan intelektual (SAVI) menganut aliran ilmu kognitif modern yang menyatakan belajar yang paling baik adalah melibatkan emosi, seluruh tubuh, semua indera, dan segenap kedalaman serta keluasan pribadi, menghormati gaya belajar individu lain dengan menyadari bahwa orang belajar dengan cara yang berbeda. Model pembelajaran ini dapat membantu guru dalam proses penyampaian materi sehingga seluruh siswa dapat belajar secara maksimal. Penerapan model pembelajaran SAVI dalam pembelajaran TIK berorientasi pada proses penyampaian materi di dalam kelas sehingga seluruh siswa dapat belajar secara maksimal karena pada dasarnya setiap siswa memiliki karakteristik yang berbeda-beda dalam proses penyerapan ilmu pengetahuan.
\end{abstract}

Kata Kunci: model pembelajaran, SAVI, TIK 


\begin{abstract}
Education takes very important rolesin individual's development, because it becomes the learning experiences in every aspects of human life. As the logic consequences, education is always faced with new problem. The education quality problem is coming from the education quality problem is coming from the education process. Moreover, the continuityof the processof education is supported by the education component; the student, teachers, and the curriculum. In teaching and learning process, TIK is all ready involved in education curriculum. Therefore, the approach of teaching and learning process is needed and the teachers is expectedto only become the facilitator in teaching and learning process. The theory of somatic, auditory, visual, and intellectual (SAVI) are part of the modern cognitive which mention that the best way in learning is involving emotion, all the parts of the body, the sense, and respecting each other. This kind of teaching and learning process helps the teachers in delivering the materials so that the students can understand well. The application of SAVI method in the teaching of TIK, concerns with the delivering of materials in class in order to make the student can learn well, because basically every students has their own characteristics in receiving knowledge.
\end{abstract}

Keywords: learning model, SAVI, TIK 


\section{Pendahuluan}

Pendidikan mempunyai tugas menyiapkan Sumber Daya Manusia (SDM) untuk pembangunan. Pendidikan adalah usaha sadar dan terencana untuk mewujudkan suasana belajar dan proses pembelajaran agar peserta didik secara aktif mengembangkan potensi dirinya untuk memiliki kekuatan spiritual keagamaan, pengendalian diri, kepribadian, kecerdasan, akhlak mulia, serta keterampilan yang diperlukan dirinya, masyarakat, bangsa dan negara (UUSPN No. 20 tahun 2003). Menurut Sagala (2008: 1), pendidikan adalah segala situasi hidup yang mempengaruhi pertumbuhan individu sebagai pengalaman belajar yang berlangsung dalam segala lingkungan dan sepanjang hidup. Sebagai konsekuensi logis, pendidikan selalu dihadapkan pada masalah-masalah baru. Mutu pendidikan dipermasalahkan jika hasil pendidikan belum mencapai taraf seperti yang diharapkan. Permasalahan mutu pendidikan lebih terletak pada masalah pemrosesan pendidikan. Selanjutnya kelancaran pemrosesan pendidikan ditunjang oleh komponen pendidikan yang terdiri dari peserta didik, tenaga pendidikan, kurikulum.

Seiring dengan perkembangan zaman, Teknologi Informasi dan Komunikasi (TIK) telah menjadi kebutuhan masyarakat luas, tidak terkecuali dalam proses pembelajaran. Teknologi informasi telah mengubah laju percepatan akses informasi dan lebih dari itu secara paradigmatik telah mengubah praktik dunia pendidikan menuju ke interaksi yang lebih intensif dengan tidak terkendala oleh ruang dan waktu. Dalam pembelajaran, TIK merupakan bagian dari ranah ilmu pengetahuan yang telah dimasukkan ke dalam kurikulum pendidikan. Oleh karena itu diperlukan pendekatan pembelajaran yang sesuai, dan guru diharapkan hanya sebagai fasilitator dalam proses belajar mengajar.
Pembelajaran ialah membelajarkan siswa menggunakan asas pendidikan maupun teori belajar yang merupakan penentu utama keberhasilan pendidikan. Pembelajaran merupakan proses komunikasi dua arah, mengajar dilakukan oleh pihak guru sebagai pendidik, sedangkan belajar dilakukan oleh peserta didik atau murid. Dalam pembelajaran guru harus memahami hakekat materi pelajaran yang diajarkan sebagai suatu pelajaran yang dapat mengembangkan kemampuan berfikir siswa untuk belajar dan perencanaan pengajaran yang matang oleh guru. Pendapat ini sejalan dengan Jerome Bruner (Sagala, 2008:63) mengatakan bahwa perlu adanya teori pembelajaran yang akan menjelaskan asasasas untuk merancang pembelajaran yang efektif di kelas. Asumsi yang masih berkembang saat ini bahwa pengetahuan dapat dipindahkan utuh dari pikiran guru ke pikiran siswa. Dengan asumsi tersebut mereka memfokuskan diri pada upaya penuangan pengetahuan ke dalam kepala para siswanya (Sadia dalam Sihite, 1997:1).

Kesulitan belajar menurut thorndike dapat terkurangi dengan adanya latihan, yaitu semakin sering tingkah laku diulang atau dilatih (digunakan), maka asosiasi tersebut akan semakin kuat. dengan tindakan akan menjadi lebih kuat karena latihan-latihan, tetapi akan melemah bila koneksi antara keduanya tidak dilanjutkan atau dihentikan. (Wasty : 2003 ) mengemukakan bahwa prinsip utama dalam belajar adalah ulangan. Hubungan stimulus dan respon akan bertambah erat jika sering dipakai dan akan berkurang bahkan lenyap jika tidak pernah digunakan, artinya dalam kegiatan belajar diperlukan adanya latihan-latihan dan pembiasaan agar apa yang dipelajari dapat diingat lebih lama. Semakin sering berlatih maka akan semakin paham. sebagaimana yang dikemukakan oleh Mc.Keachie 
bahwa individu merupakan "manusia belajar yang aktif selalu ingin tahu".

Dalam proses belajar, siswa harus menampakkan keaktifan. Keaktifan itu dapat berupa kegiatan fisik yang mudah diamati maupun kegiatan psikis yang sulit diamati. Kegiatan fisik bisa berupa membaca, mendengar, menulis, berlatih keterampilan-keterampilan dan sebagainya. Kegiatan psikis misalnya menggunakan pengetahuan yang dimiliki dalam memecahkan masalah yang dihadapi, membandingkan suatu konsep dengan yang lain, menyimpulkan hasil percobaan dan lain sebagainya.

Teori pembelajaran somatis, auditori, visual, dan intelektual (SAVI) menganut aliran ilmu kognitif modern yang menyatakan belajar yang paling baik adalah melibatkan emosi, seluruh tubuh, semua indera, dan segenap kedalaman serta keluasan pribadi, menghormati gaya belajar individu lain dengan menyadari bahwa orang belajar dengan cara-cara yang berbeda (Slavin, 2008). Model pembelajaran ini dapat membantu guru dalam proses penyampaian materi di dalam kelas sehingga seluruh siswa dapat belajar secara maksimal karena pada dasarnya setiap siswa memiliki karakteristik yang berbeda-beda dalam proses penyerapan ilmu pengetahuan.

\section{Metode Penelitian}

Metode penelitian ini menggunakan studi kepustakaan. Pennulisan ini dikaji secara deskriptif kualitatif. Sumber dari penulisan ini diambil melalui jurnal-jurnal ilmiah, artikel dan buku. Data yang didapat dari sumber tersebut diolah dengan cara mempelajari hasil dari pencarian data, yang kemudian dibuat rangkuman dan diperoleh kesimpulan dari studi pustaka.

\section{Hasil Penelitian dan Pembahasan}

Implementasi dari model pembelajaran SAVI pada pada mata pelajaran TIK dapat diambil contoh pada pokok bahasan perangkat lunak pengolah angka. Dimana banyak dijumpai kasus jumlah komputer yang ada di laboratorium komputer yang tidak sebanding dengan jumlah siswa setiap kelas, dengan metode ini siswa dapat berinteraksi dengan temannya dan dapat mengetahui kekurangan dan kelebihan dari diskusi yang berlangsung di kelas. Sehingga pemikiran siswa menjadi lebih luas dan pada dasarnya siswa memiliki cara yang berbeda-beda dalam menyerap materi pelajaran yang diberikan oleh guru.

$$
\text { Pembelajaran SAVI dapat }
$$

direncanakan dan kelompok dalam empat tahap yaitu. (1) Tahap persiapan (kegiatan pendahuluan). Pada tahap ini guru membangkitkan minat siswa, memberikan perasaan positif mengenai pengalaman belajar yang akan datang, dan menempatkan mereka dalam situasi optimal untuk belajar. Pada proses pembelajaran TIK, dalam tahapan ini guru akan melakukan persiapan pengajaran, baik itu penyiapan tempat dan media pembelajaran. Melakukan absensi serta menempatkan siswa pada kelompokkelompok menurut jumlah computer yang tersedia di laboratorium. Setelah itu guru membangkitkan ingatan siswa mengenai materi pembelajaran sebelumnya serta memberikan pandangan positif mengenai materi pembelajaran yang mereka pelajari untuk digunakan untuk kehidupan mereka sehingga siswa termotivasi untuk mempelajari materi yang akan diajarkan.(2)Tahap penyampaian (kegiatan inti). Pada tahap ini guru hendaknya membantu siswa menemukan materi belajar yang baru dengan cara menari, menyenangkan, relevan, melibatkan pancaindera, dan cocok untuk semua gaya belajar. Pada pembelajaran TIK, pada tahapan ini guru mencoba untuk menyampaikan materi pembelajaran dengan inovatif dan mempresentasikan materi pelajaran secara menarik sehingga siswa tertarik dan cepat mengerti akan 
materi yang disampaikan. (3)Tahap pelatihan (kegiatan inti). Pada tahap ini guru hendaknya membantu siswa mengintegrasikan dan menyerap pengetahuan dan keterampilan baru dengan berbagai cara. Pada pembelajaran TIK, guru memulai aktivitas siswa dengan melakukan pelatihan-peatihan terhadap materi yang sudah diajarkan dan mempraktekkannya langsung pada computer yang tersedia. Setelah itu siswa diberikan untuk melakukan proses tanya jawab untuk memecahkan persoalan yang terdapat di LKS pengajaran. (4) Tahap penampilan hasil (kegiatan penutup).

Pada tahap ini guru hendaknya membantu siswa menerapkan dan memperluas pengetahuan atau keterampilan baru mereka pada pekerjaan sehingga hasil belajar akan melekat dan penampilan hasil akan terus meningkat. Pada pembelajaran TIK, disini masing-masing kelompok siswa menampilkan hasil praktek yangtelah mereka diskusikan dalam kelas, dan terjadi evaluasi kerja serta umpan balik siswa dan guru pada saat mereka belum mengerti tentang materi pembelajaran yang digunakan.

\section{Gambar dan Tabel}

Tabel 1. Implementasi SAVI

\section{Langkah-langkah Pembelajaran}

\section{Kegiatan Pendahuluan}

- Guru melakukan koordinasi kelas (Auditori)

- Guru melakukan apersepsi dengan menyampaikan tujuan pembelajaran (Auditori)

- Guru membentuk siswa dalam beberapa kelompok kecil berdasarkan jumlah komputer yang tersedia. (Somatis)

\section{Kegiatan Inti}

Eksplorasi

- Guru menyampaikan materi pelajaran dengan melakukan simulasi materi pembelajaran langsung pada lembar kerja perangkat lunak pengolah angka dan siswa mengamati melalui media LCD. (Visual)

- Dengan diskusi ,siswa dapat menjelaskan materi yang ia Langkah-langkah Pembelajaran

mengerti dari penjelasan dan simulasi guru kepada teman diskusinya yang belum mengerti (Auditori)

- Guru menyuruh siswa untuk mengerjakan latihan soal yang terdapat di dalam LKS. (Intelektual)

Elaborasi

- Guru melakukan rolling kelompok kepada siswa untuk menyimak materi yang belum mereka mengerti (Somatis, -Visual)

- Siswa kembali kepada kelompoknya masing - masing. (Somatis)

- Siswa bersama kelompoknya mempraktekkan dan berdiskusi menjawab soal yang terdapat dalam LKS. (Somatis, Auditori, Visual, Intelektual)

Konfirmasi

- Guru membahas soal yang terdapat dalam LKS dengan menyuruh siswa untuk maju ke depan kelas membaca serta langsung menyampaikan hasil kerjanya. (Somatis, Auditori, Visual, Intelektual)

- Siswa yang lain memberi tanggapan dan diberi kesempatan untuk memperbaiki jawaban dari temannya jika terjadi kesalahan (Somatis, Auditori, Intelektual)

- Guru menyampaikan hal - hal yang perlu diperbaiki terhadap hasil pekerjaan siswa (Auditori)

- Guru memberikan kesempatan kepada siswa untuk bertanya jika ada hal hal yang belum dimengerti( Auditori)

- Guru memberikan penguatan dan umpan balik kepada siswa. ( Auditori)

\section{Kegiatan Penutup}

- Siswa bersama guru menyimpulkan materi 


\begin{tabular}{|l|}
\hline \multicolumn{1}{|c|}{ Langkah-langkah Pembelajaran } \\
\hline pembelajaran yang dibahas (Auditori, \\
Intelektual) \\
\hline Kegiatan Penutup \\
\hline - Siswa bersama guru menyimpulkan \\
materi pembelajaran yang dibahas. \\
(Auditori, Intelektual) \\
\hline - Guru mengadakan evaluasi terhadap \\
proses pembelajaran. (Auditori, \\
Intelektual) \\
\hline - Guru memberikan tindak lanjut. \\
(Auditori, Intelektual) \\
\hline
\end{tabular}

\section{Kesimpulan dan Saran}

Teori pembelajaran somatis, auditori, visual, dan intelektual (SAVI) menganut aliran ilmu kognitif modern yang menyatakan belajar yang paling baik adalah melibatkan emosi, seluruh tubuh, semua indera, dan segenap kedalaman serta keluasan pribadi, menghormati gaya belajar individu lain dengan menyadari bahwa orang belajar dengan cara-cara yang berbeda.

Teknologi informasi dan komunikasi (TIK) membawa paradigma baru dalam pendidikan yaitu perubahan dari pembelajaran tradisional ke pembelajaran baru.

Penerapan model pembelajaran somatis, auditori, visual, dan intelektual (SAVI) dalam pembelajaran TIK berorientasi pada proses penyampaian materi di dalam kelas sehingga seluruh siswa dapat belajar secara maksimal karena pada dasarnya setiap siswa memiliki karakteristik yang berbeda-beda dalam proses penyerapan ilmu pengetahuan.

Sebagai tindak lanjut dari penerapan teori ini yaitu guru atau pengajar menyediakan modul-modul pembelajaran yang dapat dipelajari oleh siswa, selain itu guru juga menyiapkan media pembelajaran guna menjelaskan materi didepan kelas agar sebelum praktek, siswa lebih dahulu memahami materi yang akan dipraktekkannya. Dan menyediakan soalsoal sebagai latihan praktek siswa dalam proses memahami materi pelajaran yang sedang diajarkan.

\section{Daftar Pustaka}

Depdiknas. 2003. "Naskah Akademik Kajian Kebijakan Kurikulum Mata Pelajaran TIK". Jakarta : Departemen Pendidikan Nasional.

Munir. (2008). Kurikulum berbasis teknologi informasi dan komunikasi. Bandung: Alfabeta.

Noni, N. 2010. "Penerapan Teknologi Informasi dan Komunikasi (TIK) Dalam Pendidikan". Tersedia pada http:// blog. unm. ac.id /nurdinnoni /files /2010 /04/Modul-1.pdf. Diakses tanggal 2 Januari 2013.

Purbo,Onno. 2009. Buku Pelajaran Teknologi Informasi dan Komunikasi Untuk SMP/MTs Kelas VIII. Jakarta : Kementrian Riset dan Teknologi.

Slavin, Robert E. 2008. Cooperative Learning Teor, Riset, dan Praktik. Bandung : Nusa Media.

Wahidin. (2009). "Pemanfaatan Teknologi Informasi Dan Komunikasi Sebagai Media Pembelajaran. Tersedia pada http://makalahkumakalahmu.wordpress .com /2009/03/18/pemanfaatanteknologi-informasi-dan-komunikasisebagai-media-pembelajaran/. Diakses tanggal 2 Januari 2013.

Wena, Made.2010.Strategi Pembelajaran Inovatif Kontemporer.Jakarta:PT Bumi Aksara. 
